\title{
Advanced Perspectives for Modeling Simulation and Control of Power Electronic Systems
}

\author{
Michal Frivaldsky
}

Citation: Frivaldsky, M. Advanced Perspectives for Modeling Simulation and Control of Power Electronic Systems. Energies 2021, 14, 8108. https://doi.org/10.3390/en14238108

Received: 18 November 2021

Accepted: 2 December 2021

Published: 3 December 2021

Publisher's Note: MDPI stays neutral with regard to jurisdictional claims in published maps and institutional affiliations.

Copyright: (C) 2021 by the author. Licensee MDPI, Basel, Switzerland. This article is an open access article distributed under the terms and conditions of the Creative Commons Attribution (CC BY) license (https:// creativecommons.org/licenses/by/ $4.0 /)$.
Department of Mechatronics and Electronics, Faculty of Electrical Engineering and Information Technologies, University of Zilina, Univerzitna 1, 01026 Zilina, Slovakia; michal.frivaldsky@fel.uniza.sk

Power electronic systems have become a major issue related to advancements in consumer and industrial electronics. Their fast-growing development can be observed within any electronic device of daily use. Here, we can talk about consumer electronics such as cell phones and laptops, or transport systems such as e-scooters or electromobility. The development of energy storage systems and intelligent smart grid systems is another area that has penetrated our daily lives and changed the way we look at the efficient use of electricity.

The continual rate of the use of electronic components in any application area is enormous. Together with this phenomenon, it is important to secure relevant sustainability and operation ability. This means that with the increased use of electronic systems, the use of energy storage systems, control systems and safety systems requires continual improvements and research of the new strategies and technologies as well.

At present, global society is at a point where it is necessary to direct the development of technology in a way that will allow the natural continuity of technological progress to be maintained without major environmental changes.

First of all, it is necessary to optimize the development of any industrial or consumer products so that their recycling rate is as high as possible. It is also necessary to take into account and emphasize the need to optimize the use of energy resources. Electricity is currently one of the purest forms, but the process of producing or consuming it requires highly efficient electronic systems.

As the research and development of such systems are complex problems, there is a way to create accurate simulation models of electronic systems, and their operating processes are highly efficient. Efficiency in this sense means significant savings in both material and energy resources. Through accurate simulation models, it is possible to carry out a wide range of experiments, still in the pre-production stage of the target device.

The issue of the simulation of not only electronic systems dates to the early $80 \mathrm{~s}$. In connection with advances in the field of information systems as well as in the field of the technological process of semiconductor component production, there is currently a widespread expansion in the use of various simulation tools.

With the help of simulation analyses, it is currently possible to analyze almost every physical event. Thanks to this technical progress, the approach to the development and design of electronic devices is now much more precise than in the past. Simulation tools elegantly allow us to perform a wide range of in-depth analyses relevant to the use of the target product.

This Special Issue is devoted to the possibilities of using different approaches for creating computer models of high-performance electronic systems. The articles in this Special Issue are devoted to various issues, including the modeling of electromagnetic processes through FEM analysis, the creation of HIL simulations or the development of control algorithms for power semiconductor converters.

Based on the submitted topics, it is seen that modeling and simulation tools represent a valuable design approach if the research and development of simple or complex power 
electronic systems and their control are considered. The techniques improving the validity of the models are increasing the credibility of the results obtained by simulations, thereby speeding up the process required to develop prototypes of power electronic systems. The contribution of this Special Issue involves eight papers:

- Collective Losses of Low Power Cage Induction Motors-A New Approach [1];

- $\quad$ Analysis of Influence Factors for Heat Generation Minimization of DC-Link Capacitor [2];

- In Loop Design of the Coils and the Electromagnetic Shielding Elements for the Wireless Charging Systems [3];

- Analysis and Design Guidelines for Current Control Loops of Grid-Connected Converters Based on Mathematical Models [4];

- Optimal Combination Design of a Light Emitting Diode Matrix Applicable to a SingleStage Flyback Driver [5];

- Modeling of a Quasi-Resonant DC Link Inverter Dedicated to Common-Mode Voltage and Ground Current Reduction [6];

- A Corrected Equilibrium Manifold Expansion Model for Gas Turbine System Simulation and Control [7];

- A Study of Interpolation Compensation Based Large Step Simulation of PWM Converters [8].

As can be seen from the titles of the papers, the simulation analysis procedure is currently a powerful tool that is increasingly used in a wide range of analyses of power electronic systems.

Funding: This research received no external funding.

Conflicts of Interest: The author declares no conflict of interest.

\section{References}

1. Szychta, E.; Szychta, L. Collective Losses of Low Power Cage Induction Motors-A New Approach. Energies 2021, 14, 1749. [CrossRef]

2. Jeon, Y.W.; Kim, Y.S.; Jeon, E.S. Analysis of Influence Factors for Heat Generation Minimization of DC-Link Capacitor. Energies 2021, 14, 114. [CrossRef]

3. Frivaldsky, M.; Pavelek, M. In Loop Design of the Coils and the Electromagnetic Shielding Elements for the Wireless Charging Systems. Energies 2020, 13, 6661. [CrossRef]

4. Abad, G.; Sanchez-Ruiz, A.; Valera-García, J.J.; Milikua, A. Analysis and Design Guidelines for Current Control Loops of Grid-Connected Converters Based on Mathematical Models. Energies 2020, 13, 5849. [CrossRef]

5. Tsou, M.-C.; Kuo, M.-T. Optimal Combination Design of a Light Emitting Diode Matrix Applicable to a Single-Stage Flyback Driver. Energies 2020, 13, 5209. [CrossRef]

6. Turzyński, M.; Frivaldsky, M. Modeling of a Quasi-Resonant DC Link Inverter Dedicated to Common-Mode Voltage and Ground Current Reduction. Energies 2020, 13, 5090. [CrossRef]

7. Zhu, L.; Liu, J.; Ma, Y.; Zhou, W.; Yu, D. A Corrected Equilibrium Manifold Expansion Model for Gas Turbine System Simulation and Control. Energies 2020, 13, 4904. [CrossRef]

8. Li, Y.; Deng, P.; Zhang, J.; Liu, D.; Hao, Z. A Study of Interpolation Compensation Based Large Step Simulation of PWM Converters. Energies 2020, 13, 3069. [CrossRef] 